\title{
Effect of Dividend Payment on Stock Prices of Commercial Banks in Nepal: Panel Approach
}

\author{
Yuga Raj Bhattarai, PhD. \\ Associate Professor, Tribhuvan University, Patan Multiple Campus, Nepal \\ E-mail: yugarajbhattarai@gmail.com
}

\begin{abstract}
This study has examined the effect of dividend payment on stock prices of commercial banks in Nepal. The study has adopted causal comparative research design. The secondary data of six commercial banks were collected during 7 years (2010 to 2016) period. Data were analyzed using both descriptive and inferential statistics. From the empirical analysis this study found a significant positive relationship between share price and dividend payment. This study concludes that payment of dividend positively affect share price of Nepalese commercial banks.
\end{abstract}

Keywords: Banks, Dividend, Panel Data, Stock Prices, Nepal

JEL Classification:C23, C33, C87, G12, G21, G35

\section{INTRODUCTION}

The share price of commercial banks is a matter of concern not only to the management of the bank but also to other stakeholders such as investors, employees, depositors and borrowers. Stock price is often used as an indicator of firm value. The rise in stock price will generally enhance stockholders wealth. The stock prices of commercial banks fluctuate widely overtime. There is need to fairly predict and anticipate changes in the upcoming stock prices. Kapoor (2009) asserts that share prices of a firm tend to be reduced whenever there is a reduction in dividend payments. Moreover, Bishop, Harvey, Crapp, Faff, and Twite (2000) contend that managers must not only consider the question of how much of the company's earnings are needed for investment, but also take into consideration the possible effect of their decisions on share prices. An announcement of dividend increase can generate abnormal positive security returns and an announcement of dividend decrease may generate abnormal negative security returns. Thus, reduction in share prices may occur when banks reduce dividend payments to their shareholders.

Since the bank management is generally dealing with competing interests of various shareholders, the kind of dividend policy they adopt may have either positive or negative effects on the share prices of the banks. Selecting a suitable dividend policy 
is an important decision for the bank because flexibility to invest in the future depends on the amount of dividends that they pay to their shareholders. The effect of a firm's dividend policy on the current price of its shares is a matter of considerable importance, not only to the corporate officials, who must set the policy, but to investors planning portfolios and to economists seeking to understand and appraise the functioning of the capital markets (Miller \& Modigliani, 2061). It is important for investors because investors consider dividends not only the source of income but also a way to assess company from investment point of view (Gordon, 1963). Thus, dividend policy cannot be over-emphasized because it may have direct impact on share price.

Effect of dividend policy on stock prices has remained debatable issue among managers, policy makers and researchers for many years since Miller and Modigliani (1961) dividend hypothesis. Miller and Modigliani (1961 have asserted that given firms optimal investment policy, the firm's choice of dividend policy has no impact on shareholders wealth. However, Gordon (1963) argues that dividend policy does affect the value of firm and market price of shares. The author asserts that shareholders prefer the early resolution on uncertainty, and will pay a higher price for a share which has a greater dividend payout ratio. The author contends that investors always prefer secure and current income in the form of dividends over capital gains. Various studies such as Travlos, Trigeorgis, and Vafeas (2001), Baker, Powell, and Veit (2002), Myers and Frank (2004), Dong, Robinson, and Veld (2005), Maditinos, Sevic, Theriou, and Tsinani (2007) have supported dividend relevance theory. Gustavo and Michaely (2007) conclude that changes in dividend policy convey news about future cash flows; specifically, dividend increases convey good news and dividend decreases convey bad news. These past empirical evidences have indicated a strong relationship between dividend changes and price volatility. However, Baskin (1989) has found inverse relation between stock prices and dividend policy.

Past relevant studies like Arnott and Asness (2003), Farsio, Geary and Moser (2004) mainly concentrated in developed countries. The question of relevance of dividend policy on stock prices in developing country like Nepal still remains uncover. This study has sought to fill this gap in literature by investigating the effect of dividend payment on share prices of Nepalese commercial banks using panel data.

The remainder part of this study has been organized as follows: Section two reviews the relevant literature on the subject matter. Section three discussed the methodology adopted in analyzing the data. Section four focuses on the estimation of regression models and discussion of the results. Lastly, section five concludes the study with the necessary recommendations. 


\section{LITERATURE REVIEW}

The relationship between dividend policy and share price has been examined by various researchers in different dimensions in diverse economic perspectives. Miller and Modigliani (1961) firstly introduced the concept of dividend irrelevance theory in which they explain that dividend policy does not affect stock prices. Many researchers like Black and Scholes (1974), Chen, Firth, and Gao (2002), Adefila, Oladipo and Adeoti (2004), Uddin and Chowdhury (2005), Denis and Osobov (2008), Adesola and Okwong (2009) provide the strong evidence in favour of dividend irrelevance theory, meaning that dividend does not influence share prices. Likely, Das and Samanta (2013) have pointed out that irrelevance theorem holds true in information technology sector in India in liberalized era.

However, Gordon (1963) asserted that dividend policy does affect value of the firm and market price of shares and thus, dividend is relevance. This relevancy theory is supported by various empirical studies like Travlos et al. (2001), Baker et al. (2002), Myers and Frank (2004), Dong et al. (2005), Maditinos et al. (2007), where they conclude that payment of dividend affects share price. Moreover, Pradhan (2003), Nazir, Nawaz, Anwar and Ahmed (2010), Michael and Benson (2014), Oliver, Loretta and Grace (2016) conclude that dividend payments have strong relationship with stock prices. Likely Azhagaiah and Sabaripriya (2008), Aravanan and Mannarakkal (2011) have found a strong impact of dividend policy on shareholders wealth.

Moreover, the positive relationship has been reported between dividend policy and stock prices in various studies like Attah-Botchwey (2014), Nishat and Irfan (2003), Om and Goel (2017). However, Shah and Noreen (2016) find significant negative relationship between stock price volatility and dividend policy. In addition to dividend payment, Nishat and Irfan (2003) have found positive impact of size and leverage on stock price volatility. Likely, Idawati and Wahyudi (2015) have found positive impact of EPS and ROA on stock prices. Moreover, Oliver, Loretta and Grace (2016) assert that dividend per share and earnings per share are the predominant variables influencing the share prices volatility.

An overview of selected past empirical evidences showed that share price of commercial bank could be affected by dividend payment, profitability and size. In order to test these evidences in Nepalese perspectives, this study empirically examines the effect of dividend payment on share price in "A Class" commercial banks in Nepal. 


\section{RESEARCH METHODOLOGY}

\section{Data and Sample}

The banks selected for the study were: Himalayan Bank Ltd., Nepal Investment Bank Ltd., Nabil Bank Ltd., Standard Chartered Bank Nepal Ltd., Everest Bank Ltd. and Siddhartha Bank Ltd. etc. Data from the banks in sample were collected during 7 years (2010 to 2016) period. This study has adopted convenience sampling method for choosing the banks as sample. The causal comparative research design has been employed for the study. This study is limited to the secondary data of six 'A class' commercial banks with four bank-specific variables.

\section{The Model}

The models for panel data can be arranged as: pooled regression, fixed effects, random effects and random parameters (Greene, 2007). In view of theoretical perspective, this study has employed pooled OLS model, fixed effects model and random effects model in the data analysis procedures. In this study, market price per share has been expressed as a function of dividend per share, as well as other control variables like: profitability and size. Using pooled OLS model, the equation can be written as:

$$
\mathrm{MPS}_{\mathrm{it}}=\beta_{0}+\beta_{1} \mathrm{DPS}_{\mathrm{it}}+\beta_{2} \mathrm{PROF}_{\mathrm{it}}+\beta_{3} \mathrm{SIZE}_{\mathrm{it}}+\mathrm{e}_{\mathrm{it}}
$$

Where:

MPS $_{i t}=$ Market price per share of $i^{\text {th }}$ bank in $t$ year.

$\mathrm{DPS}_{\mathrm{it}}=$ Dividend per share of $\mathrm{i}^{\text {th }}$ bank in $\mathrm{t}$ year.

$\mathrm{PROF}_{\mathrm{it}}=$ Profitability, measured as return on assets of $\mathrm{i}^{\text {th }}$ bank in $\mathrm{t}$ year.

$\mathrm{SIZE}_{\mathrm{it}}=$ Size, measured as natural logarithm of total assets of $i^{\text {th }}$ bank in $t$ year.

$\beta_{0}=$ The intercept of the regression line

$\beta_{1}, \beta_{2}, \beta_{3}=$ The slop which represents the degree with which market price per share changes as the independent variable changes by one unit variable. The priori expectation is that the coefficients $\beta_{1}, \beta_{2}$ and $\beta_{3}>0$.

$\mathrm{e}_{\mathrm{it}}=$ error term

In addition to the pooled OLS model, this study has employed other panel models like: fixed effects model and random effect model. Fixed effects estimation allows for the unobservable bank heterogeneity. Specifically, the model assumes that intercepts for each bank are allowed to vary, but the slopes for each bank are equal. In this instance, Greene (2007) has suggested following fixed effect model: 


$$
Y_{i t}=X_{i t} \beta+\alpha_{i}+\varepsilon_{i t}
$$

where, $\alpha_{i}=z_{i} \alpha$, embodies all the observable effects and specifies an estimable conditional mean. Greene (2007) assets that fixed effect approach takes $\alpha_{\mathrm{i}}$ to be a group-specific constant term in the regression model. The author reports that each $\alpha_{\mathrm{i}}$ is treated as an unknown parameter to be estimated. In some cases, fixed effects estimations become less efficient than random effects estimations. Random effects estimations take into consideration the unobservable bank heterogeneity effects, but incorporate these effects into the error terms, which are assumed to be uncorrelated with the explanatory variables. Likely, Greene (2007) has asserted that if the unobserved individual heterogeneity, however, formulated, can be assumed to be uncorrelated with the included variables, then the model may be formulated in random effect form. The random effect model suggested by Greene (2007) can be written as:

$$
Y_{i t}=X_{i t} \beta+\alpha+u_{i}+\varepsilon_{i t}
$$

According to Greene (2007) this random effects approach specifies that $u_{i}$ is a group specific random element, similar to $\varepsilon_{i t}$ except that for each group, there is but a single draw that enters the regression identically in each period. However, the $\varepsilon_{\text {it }}$ represents within entity error. In order to capture the deferring attributes of panel data, the current study has employed these three regression models to estimate the effect of dividend payment on the share price of commercial banks in Nepal. The estimation of the regression equations have been carried out using Gretl- 1.1 Version, an Econometric Software.

\section{Variables and Hypotheses}

In this study, the choice of variables was mostly affected by the approach in the past empirical studies. Moreover, due care is also taken for number of the observations in the sample, Nepalese perspective as well market condition in selecting the study variables.

\section{Dependent Variable}

\section{Market Price per Share}

In this study, market price per share is represented by annual closing price of selected banks. Based on the theoretical perspective and an overview of past empirical evidences, it hypothesized that share price of Nepalese commercial bank is affected by dividend payment and other covariates like: profitability and size. 


\section{Independent Variable}

\section{Dividend per Share}

Dividend per share relies on an accounting measure (net income). It is calculated dividing net income available to common stockholders by number of common share outstanding. In the absence of clientele effect, if the company pay larger amount of cash dividends then it will result in high market value of shares. In the same token, Akbar and Baig (2010) have found positive relation between cash dividends and stock prices. Likely, Travlos et al. (2001) have found positive relation between stock dividends and stock prices. Moreover, Joshi (2012), Munyua (2012), Asadi (2013), Oliver et al. (2016) have found significant positive effect of dividend on share price of the firm. However, Baskin (1989) found inverse relation between stock prices and dividend policy. Moreover, Miller and Modigliani (1961) have asserted that given firms optimal investment policy, the firm's choice of dividend policy has no impact on shareholders wealth. Despite the differing opinions on the current issue, in line with majority of empirical evidences, the significant positive relationship is expected between share price and dividend payment (i.e. $\beta_{1}>0$ ).

$H_{1}$ : Dividend per share has a significant and positive effect on share price.

\section{Profitability}

In this study, profitability is measured by return on assets (ROA). It indicates the ability of management to mobilize the resources of its assets into profits. The greater the profit generated, the level of stock return expected by investors will be greater or a positive value. Furthermore, investors will tend to invest in shares in these companies. This will lead to an increase in demand for stocks in the stock market. Assuming that the number of shares outstanding remains, it is certain that the stock price will move higher. Likely, the bank with higher the ROA implies the higher the bank's ability to generate profits, the higher the bank's income would make investors interested in the stock value. In this perspective, Naveed and Ramzan (2013) have found insignificant relationship between return on assets (profitability) and share price in banking sector in Pakistan. However, Idawati and Wahyudi (2015) concluded that earnings per share and return on assets have positive relationship to the stock price and simultaneously significantly affect stock prices. It is, therefore, expected that profitabilityis significantly positively associated with share price (i.e. $\beta_{2}>0$ ).

$H_{2}$ : Profitability has a significant and positive effect on share price. 
Size

Size is one of the control variable measured by using the natural logarithm of total asset (Smith \& Watts, 1992; Chae et al., 2009; Kouki\& Guizani, 2009). Past empirical evidences supported that size may affect share prices of firms. Zakaria, Muhammad and Zulkifli (2012) have found significant positive effect of size (natural logarithm of total asset) on share price volatility in Malaysian Construction and Material Companies. Likely, Naveed and Ramzan (2013) conclude that size has a positive and significant relationship with the share price. Based on these empirical evidences, it is expected that size should have positive relationship with share price (i.e. $\beta_{3}>0$ ).

$\mathrm{H}_{3}$ : Size has a significant and positive effect on share price.

\section{RESULTS AND DISCUSSIONS}

\section{Descriptive Statistics}

The descriptive statistics of the study variables have been presented in Table 1. The result shows that the minimum and maximum market prices per share are: Rs 270 and Rs 6010 respectively. Likely, the average market price per share is Rs 1,616.45. The dividend per share ranged from Rs 17.00 minimum to the maximum to Rs.110.00 among sampled commercial banks.

Table 1: Descriptive Statistics of Variables $(n=42)$

\begin{tabular}{cccccccc}
\hline Variables & Scale & Mean & $\begin{array}{c}\text { Std. } \\
\text { Deviation }\end{array}$ & Minimum & Maximum & Skewness & Ex. Kortosis \\
\hline MPS & Rupees & 1616.450 & 1205.620 & 270.000 & 6010.000 & 1.699 & 3.350 \\
DPS & Rupees & 54.238 & 26.749 & 17.000 & 110.000 & 0.584 & -0.733 \\
PROF & Percent & 2.014 & 0.522 & 1.060 & 3.250 & 0.117 & -0.634 \\
SIZE & Ln & 24.698 & 0.569 & 22.265 & 25.589 & -1.698 & 6.197 \\
\hline
\end{tabular}

Source: Annual report of sample banks and results are drawn from Gretl- 1.1 Version, an Econometric Software

The average dividend per share is Rs.54.24 and the standard deviation of the same variable is Rs 26.75 approximately. The high standard deviation implies that dividend per share is found more volatile during sample period. Likely, the average profitability (return on assets) is $2.01 \%$, which implies that in average Nepalese commercial banks earn $2.01 \%$ return by the fund invested in assets. The low standard deviation of 
profitability indicates the less volatile position of profitability in Nepalese commercial. Moreover, size is also found less volatile during sample period.

\section{Correlation Analysis}

The correlation coefficients among study variables are shown in Table 2. The results indicate that market price per share is positively correlated with dividend per share, profitability, and size. However, the relationship between size and market price per share is not found strong which is evident from the Pearson correlation coefficient of 0.153 . The results imply that market price per share tends to move in the same direction as with the changes occur in dividend per share, profitability, and size. However, the magnitudes of the relationship and their directions have been measured with the use of regression models in next section.

Table 2: Pearson Correlation Coefficients $(n=42)$

\begin{tabular}{ccccc}
\hline MPS & DPS & PROF & SIZE & Variable \\
\hline 1.000 & 0.589 & 0.497 & 0.153 & MPS \\
& 1.000 & 0.832 & 0.129 & DPS \\
& & 1.000 & 0.203 & PROF \\
& & 1.000 & SIZE \\
\hline
\end{tabular}

Source: Annual report of sample banks and results are drawn from Gretl- 1.1 Version, an Econometric Software

Moreover, the correlation matrix of the variables presented Table 2 reveals that all correlations coefficients among the independent variables are less than 0.84 , implying the few evidence of presence of multicollinearity among the independent variables. Specifically, such evidence may be indicated between profitability and dividend per share. However, the presence of multicollinearity among the independent variables is precisely tested using variance inflation factor (VIF) in next section. Despite the fact that non-presence of sever multicollinearity among the independent variables were found and thus, the variables chosen seem suitable for the regression models.

\section{Regression Analysis}

Table 3 presents the regression results of effect of dividend on the stock price of commercial banks in Nepal. The values of adjusted $R^{2}$ are 0.3023 and 0.4004 using Pooled OLS Model and Fixed Effect Model respectively. The overall explanatory power of the regression models look good with adjusted $\mathrm{R}^{2}$ reported in the regression models. The p-value $\left(\mathrm{F}_{\mathrm{Sig}}\right)$ of $\mathrm{F}$ statistics in the pooled OLS model represents that the 
model is fairly fitted well statistically. Because, the F-statistic, a measure of the overall significance of the regression, shows that the explanatory variables employed are significant at the $1 \%$ level of significance. The overall significance of the fixed effect model is proved is fairly fitted well statistically with the p-value $\left(\mathrm{F}_{\text {Sig. }}\right)$ of $\mathrm{F}$ statistics, which is also found significant at the $1 \%$ level.

The variance inflation factors (VIF) have been calculated in order to test of the presence of multicollinearity among independent variables in the pooled OLS model. The variance inflation factor (VIF) shows a value less than 3.40 for each variable. The larger the value of VIF, the more troublesome or collinear the variables and as a rule of thumb a VIF greater than 10 is unacceptable (Gujarati, 2004). The VIF less than 3.40 for each variable indicates the non-presence of multicollinearity. Thus, the independent variables chosen for the models are not suffered from multicollinearity problem.

Table 3: Regression Results $(\mathrm{n}=42)$

\begin{tabular}{|c|c|c|c|c|c|c|c|c|c|c|}
\hline \multirow[t]{2}{*}{ Variables } & \multicolumn{4}{|c|}{ Pooled OLS Model } & \multicolumn{3}{|c|}{ Fixed Effect Model } & \multicolumn{3}{|c|}{ Random Effect Model } \\
\hline & Coefficients & $\mathrm{t}$ & Sig. & VIF & Coefficients & $\mathrm{t}$ & Sig. & Coefficients & $\mathrm{t}$ & Sig. \\
\hline Constant & -3911.41 & -0.57 & 0.57 & & -4487.47 & -0.69 & 0.50 & -4185.98 & -0.64 & 0.52 \\
\hline DPS & $26.23^{*}$ & 2.47 & 0.02 & 3.26 & $33.85^{* *}$ & 3.29 & 0.002 & $30.07^{* *}$ & 2.97 & 0.01 \\
\hline PROF & -7.83 & -0.01 & 0.99 & 3.34 & -288.12 & -0.55 & 0.59 & -148.62 & -0.28 & 0.78 \\
\hline \multirow[t]{2}{*}{ SIZE } & 166.85 & 0.590 & 0.56 & 1.05 & 196.31 & 0.73 & 0.47 & 181.01 & 0.68 & 0.50 \\
\hline & \multicolumn{4}{|c|}{$\begin{array}{c}\mathrm{R}^{2}=0.353 ; \text { Adj. } \mathrm{R}^{2}=0.302 \\
\mathrm{~F}=6.922 ; \mathrm{P} \text {-value }(\mathrm{F})=0.001 \\
\text { D.W. }=1.087, \quad \mathrm{P} \text {-value }(\mathrm{DW})= \\
0.010\end{array}$} & \multicolumn{3}{|c|}{$\begin{array}{c}\mathrm{R}^{2}=0.517 ; \text { Adj. } \mathrm{R}^{2}=0.400 \\
\mathrm{~F}=4.422, \quad \mathrm{P} \text {-value }(\mathrm{F})= \\
0.001 \\
\text { D.W. }=1.450 \\
\text { P-value }(\mathrm{DW})=0.027\end{array}$} & \multicolumn{3}{|c|}{$\begin{array}{l}\text { S. E. of regression }=995.837 \\
\text { Breusch-Pagan test: } \\
\text { Chi-square }(1)=1.636 \\
\text { P-value }=0.201 \\
\text { Hausman test: } \\
\text { Chi-square }(3)=4.1415 \\
\text { P-value }=0.2466\end{array}$} \\
\hline
\end{tabular}

**Significant at the 0.01 level (2-tailed),* Significant at the 0.05 level (2-tailed), Results are drawn from Gretl-1.1 Version, an Econometric Software.

The empirical finding of the current study show that market price per share is positively related to dividend per share in three models estimated. The coefficient is statistically significant at 5 percent level of significance in pooled OLS model but it is significant at 1 percent level of significance in Fixed Effect and Random effect model. The results show that increase in dividend will amplify market price per share of Nepal commercial banks. This result supports the findings of Travlos et al. (2001), Akbar and Baig (2010), Joshi (2012), Munyua (2012), Asadi (2013), Oliver, Loretta and 
Grace (2016), where they have found significant positive effect of dividend on share price of the firms.

However, the result of this study is found inconsistent with the finding of Baskin (1989), where the author has found inverse relation between stock prices and dividend policy. Moreover, the empirical evidence of this study does not support the proposition of Miller and Modigliani (1961), where they have asserted that given firms optimal investment policy, the firm's choice of dividend policy has no impact on shareholders wealth.

Profitability is found negatively associated with market price per share in three models used, however, the regression coefficients of profitability are found statistically insignificant. The results indicate that profitability has nominal effect on market price per share of commercial banks in Nepal. This result is contrary to priori expectation and the possible reason of such result could be justified on ground that Nepalese commercial banks earn low return on their assets which may not be the positive signal to the potential investors. Moreover, the coefficient of bank size is positive, but it is also statistically insignificant in three models estimated. Thus, bank size doesn't appear as an influencing variable for stock price determination of commercial banks in Nepalese context.

\section{CONCLUSION AND RECOMMENDATIONS}

This study has investigated the effect of dividend payment on share prices of commercial banks in Nepal. The causal comparative research design has been adopted for the study. The panel data of 6 commercial banks were collected during 7 years (2010 to 2016) period from the annual reports of the banks in the sample. The data were analyzed using Pooled OLS Model, Fixed Effect Model and Random Effect Model. The dependent variable used in the study was share price and independent variable chosen was dividend per share. Moreover, the profitability and size were introduced simultaneously as control variables with dividend per share in the regression models. The estimated regression models reveal that dividend per share has positive and statistically significant impact on share price of commercial bank. However, profitability and size have negligible impact on share price of commercial bank. Thus, this study concludes that increase in dividend payment can enhance the share price of the commercial banks in Nepal.

As a policy recommendation, an increase in the cash dividend is suggested to all commercial banks in Nepal that would help to induce their share prices. Further, the result of the study is based on 42 observations; there is the room for in-depth analysis using more sample observations with sophisticated econometric methods. Moreover, 
the study is limited to three bank specific independent variables and thus, further study should be carried out on the topic employing other bank specific, industry related, and macro level variables to originate more reliable results. Despite the fact, this study is hoped to be useful to academicians as a source of knowledge for further research and it may be of help for policy makers in banking sector for pushing share price and market index.

\section{References}

Adefila, J. J., Oladipo, J. A., \& Adeoti, J. O. (2004). The effect of dividend policy on the market price of shares in Nigeria: Case study of fifteen quoted companies. International Journal of Accounting, 2(1), 82-91.

Adesola, W. A., \& Okwong, A. E. (2009). An empirical study of dividend policy of quoted companies in Nigeria. Global Journal of Social Sciences, 8(1), 85-101.

Akbar, M., \& Baig, H.H. (2010). Reaction of stock prices to dividend announcements and market efficiency in Pakistan. The Lahore Journal of Economics, 15(1), 103125.

Aravanan, S.,\& Mannarakkal, M. (2011). The impact of dividend policy on shareholders' wealth (a study with reference to Ferro Alloy and Alloy Steel Industry in India). International Journal of Research in Commerce and Management, 2(1), 110117. Available at: http:// www.ijrcm.org.in

Arnott, R., \& Asness, C. (2003). Surprise! Higher dividends - higher earnings growth. Financial Analysts Journal, 59(1), 70-87.

Asadi, A. (2013). Examining the relationship between the dividend policy and stock prices in companies listed on Tehran Stock Exchange. Research Journal of Applied Sciences, Engineering and Technology, 6(22), 4186-4191.

Attah-Botchwey, E. (2014). The impact of dividend payment on share price of some selected listed companies on the Ghana Stock Exchange. International Journal of Humanities and Social Science, 4(9), 179-190.

Azhagaiah, R., \& Sabaripriya, N. (2008). The impact of dividend policy on shareholders' wealth. International Research Journal of Finance and Economics, 20, 180-187.

Baker, H. K., Powell, G.E., \&Veit, E.T. (2002). Revisiting managerial perspectives on dividend policy. Journal of Economics and Finance, 26, 267-283.

Baskin, J. (1989). Dividend policy and the volatility of common stock. Journal of Portfolio Management, 3(15), 19-25. 
Bishop, S.R., Harvey, R. Crapp, R., Faff, W., \&Twite, G.J. (2000). Corporate finance. Sydney: Prentice Hall Inc.

Black, F., \& Scholes, M. (1974). The effects of dividend yield and dividend policy on common stock prices and returns. Journal of Financial Economics, 1(1), 1-22.

Chae, J., Kim, S., \& Lee, E. J. (2009). How corporate governance affects payout policy under agency problems and external financing constraints. Journal of Banking E Finance, 33, 2093-2101.

Chen, G., Firth, M., \&Gao, N. (2002). The information content of concurrently announced earnings, cash dividends, and stock dividends: An investigation of the Chinese stock market. Journal of International Financial Management and Accounting, 2(13), 101-124.

Das, A., \& Samanta, A. (2013). Stock price behaviour and dividend policy: An empirical investigation in information technology sector of corporate India in liberalized era. International Journal of Marketing, Services \& Management Research, 2(9), 146153. Available at: http:// www.indianresearchjournals.com

Denis, D. J., \& Osobov, I. (2008). Why do firms pay dividends? International evidence on the determinants of dividend policy. Journal of Financial Economics, 89(1), 62-82.

Dong, M., Robinson, C., \& Veld, C. (2005). Why individual investors want dividends. Journal of Corporate Finance, 1(12), 121-158.

Farsio, F., Geary, A., \& Moser, J. (2004). The relationship between dividends and earnings. Journal for Economic Educators, 4(4), 1-5.

Gordon, M. J. (1963). Optimal investment and financing policy. The Journal of Finance, $18,264-272$.

Greene, W. H. (2007). Econometric analysis. Upper Saddle River, New Jersey: Pearson Prentice Hall.

Gujarati, D.N. (2004). Basic econometrics ( $4^{\text {th }}$ ed.). New York: The McGraw Hill.

Gustavo, G., \& Michaely, R. (2007). Corporate payout policy and product market competition. Working Paper, Cornell University.

Idawati, W., \& Wahyudi, A. (2015). Effect of earning per shares (EPS) and return on assets (ROA) against share price on coal mining company listed in Indonesia stock exchange. Journal of Resources Development and Management, 7, 79-91. Available at: http:// www.iiste.org

Joshi, R. (2012). Effects of dividends on stock prices in Nepal.NRB Economic Review,24(2), 61-75. 
Kapoor, S. (2009). Impact of dividend policy on shareholders' value: a study of Indian Firms (Unpublished doctoral thesis). Jaypee Institute of Information Technology (A Deemed University), Noida, India.

Kouki, M. \& Guizani, M. (2009). Ownership structure and dividend policy evidence from the Tunisia stock market. European Journal of Scientific Research, 25(1), 4253.

Maditinos, D.I., Sevic, Z., Theriou, N.G., \& Tsinani, A.V. (2007). Individual investors' perceptions towards dividends: The case of Greece. International Journal of Monetary Economics and Finance, 1(1), 18-31.

Michael, O.O. \& Benson, A.K. (2014). The impact of dividend policy on stock prices of quoted firms in Nigeria. International Journal of Economics, Commerce and Management, 2(9), 1-17. Available at: http://ijecm.co.uk/

Miller, M.H. \& Modigliani, F. (1961). Dividend policy, growth, and the valuation of shares. The Journal of Business, 34(4), 411-433. Available at: http://about.jstor. org/terms

Munyua, P.N. (2012). Effect of dividend policy on stock prices for firms listed at the Nairobi securities exchange (Unpublished master's research project). University of Nairobi, Nairobi.

Myers, M., \& Frank, B. (2004). The determinants of corporate dividend policy. Academy of Accounting and Financial Studies Journal, 8(3), 17-28.

Naveed, M.Y. \& Ramzan, M. (2013). A view about the determinants of change in share prices: A case from Karachi stock exchange (banking sector). Interdisciplinary Journal of Contemporary Research in Business, 4(12), 41-57.

Nazir, M.S., Nawaz, M.M., Anwar, W. \& Ahmed, F. (2010). Determinants of stock price volatility in Karachi stock exchange: The mediating role of corporate dividend policy. International Research Journal of Finance and Economics,55, 100107. Available at: http://www.eurojournals.com/finance.htm

Nishat, M., \& Irfan, C.M. (2003). Dividend policy and stock price volatility in Pakistan. 11th Pacific Basin Finance, Economics and Accounting Conference.

Oliver, E., Loretta, P.E. ,\&Grace, U. (2016). Dividend policy and share price volatility: A co-integration analysis. International Journal of Advanced Academic Research 1 Social \& Management Sciences,2(8), 59-75. Available at: http:// www.ijaar.org

Om, H., \& Goel, S. (2017). Analysis of factors affecting stock price behaviour: A study on listed companies in Bombay stock exchange. Imperialjournal of Interdisciplinary Research, 3(3), 115-119. Available at: http://www.onlinejournal.in 
Pradhan, R.S. (2003). Effects of dividends on common stock prices: the Nepalese evidence. In Research in Nepalese Finance. Kathmandu: Buddha Academic Publishers \& Distributors Pvt. Ltd.

Shah, S. A., \& Noreen, U. (2016). Stock price volatility and role of dividend policy: Empirical evidence from Pakistan. International Journal of Economics and Financial Issues, 6(2), 461-472. Available at: http://www.econjournals.com

Smith, C.W. Jr. \& Watts, R.L. (1992). The investment opportunity set and corporate financing, dividend, and compensation policies. Journal of Financial Economics, 32(3), 263-292.

Travlos, N., Trigeorgis, L., \& Vafeas, N. (2001). Shareholder wealth effects of dividend policy changes in an emerging stock market: The case of Cyprus. Multinational Finance Journal, 5(2), 87-112.

Uddin, M. H., \& Chowdhury, G.M. (2005). Effects of dividend announcement on shareholders' value: evidence from Dhaka stock exchange. Journal of Business Research, 7, 61-72.

Zakaria, Z., Muhammad, J., \&Zulkifli, A.H. (2012). The impact of dividend policy on the share price volatility: Malaysian construction and material companies. International Journal of Economics and Management Sciences, 2(5), 1-8. 